\title{
EUGENIA E HIGIENIZAÇÃO: A EDUCAÇÃO EUGÊNICA PARA CRIANÇAS APLICADAS NA REDE PÚBLICA DE ENSINO A PARTIR DO LIVRO "A FADA HYGIA" DE RENATO KEHL DE 1937
}

\section{EUGENY END HYGIENIZATION: THE EUGENIC EDUCATION APPLIED FOR CHILDREN OF PUBLIC EDUCATION BASED ON RENATO KEHL'S BOOK “A FADA HYGIA" OF 1937}

Jaqueline Bevilacqua Zamarchi ${ }^{2}$

Resumo: O presente artigo busca discutir a obra A Fada Hygia de Renato Kehl, mais especificamente sua quinta edição, lançada em 1937, com o objetivo de identificar em quais partes e de que modo o discurso eugenista se encontra presente na obra de cunho infantil utilizada no processo de alfabetização no início do século XX. Para tal, será discutido inicialmente como as teorias eugênicas surgiram e o contexto que permitiu sua legitimação e rápida propagação no Ocidente. Logo após será abordado o momento em que a eugenia se estabelece no Brasil e as particularidades que ela veio a desenvolver em solo brasileiro, tendo foco principal sobre Renato Kehl, um dos maiores expoentes da eugenia no país. Juntamente com a análise final da obra, essas discussões levam à compreensão da forma pela qual uma elite brasileira agiu e se utilizou da educação pública para propagar seus ideais políticos e ideológicos a fím de moldar a nação de acordo com suas concepções.

Palavras-chave: Eugenia; Higiene; Educação eugênica; Renato Kehl.

\footnotetext{
${ }^{1}$ Este artigo é resultado de pesquisa de Iniciação Científica realizada como bolsista da Fundação Araucária. Uma versão preliminar deste artigo também foi desenvolvida para a disciplina de Tópicos Especiais I do curso de Licenciatura em História da Unicentro, Campus Avançado de Coronel Vivida (Paraná).

${ }^{2}$ Graduanda do quarto ano de Licenciatura em História pela Universidade Estadual do Centro-Oeste (UNICENTRO). Email para contato: jaque_bzamarchi@live.com. Endereço para o Currículo Lattes: http://lattes.cnpq.br/6429720386098387.
} 
Abstract: This article aims to discuss the book A Fada Hygia by Renato Kehl, specifically its 5th edition launched in 1937, in order to identify where and how the eugenicist discourses are present in this children's imprint work used in the literacy acquisition process in the early twentieth century. This work will initially discuss how eugenic theories emerged as well as the circumstances that allowed their legitimation and also how it spread fast in the West. Moreover, this paper will present the moment when the eugenic practice was established in Brazil and the particularities that it brought to this country, focusing on Renato Kehl, the writer who was one of the greatest exponents of eugenics in Brazil and author of the literary work. In addition to the final analysis of this book, these discussions lead to understanding how the Brazilian elite used their access to the national public education system to propagate their political and ideological ideas in order to shape the country according to their own conceptions.

Keywords: Eugenics; Hygiene; Eugenic education; Renato Kehl.

\section{Introdução}

O movimento eugenista inicia-se na segunda metade do século XIX tendo por fundamentação o livro de Francis Galton $O$ Gênio Hereditário. Em sua obra, Galton disserta sobre a espécie humana e seu processo de desenvolvimento tanto físico quanto intelectual. Uma de suas principais inspirações para a construção dela é a publicação do livro A Origem das Espécies, de seu primo Charles Darwin. Ao lê-lo, Galton se apropria de suas partes e com os resultados dessa apropriação desenvolve as teorias eugenistas, postulando que, ao contrário do que Darwin colocava, o ambiente não era o principal fator de influência sobre o desenvolvimento humano, mas sim a posse de uma hereditariedade proveniente de uma 
família exemplar em vários sentidos - intelectual, físico, moral (STEPAN, 2005).

Essas teorias se proliferam de forma rápida pelos continentes europeu e americano, primeiramente nos Estados Unidos e depois na América Latina, com uma singela diferença temporal, pois como é posto por Nancy Stepan, uma sociedade eugênica é fundada no Brasil em 1918, "apenas dez anos depois da sociedade britânica equivalente e seis anos após a francesa, [o que] sugere quão sintonizados estavam os cientistas brasileiros com os desenvolvimentos científicos europeus" (STEPAN, 2004: 334).

Segundo Vanderlei de Souza (2006), à frente dessa sociedade eugênica esteve Renato Kehl, filho de descendentes alemães ligados à indústria farmacêutica no estado de São Paulo. Formado inicialmente em Farmácia a desejo do pai, Kehl decide em 1910 cursar medicina no Rio de Janeiro, local onde acaba tendo contato com os ideais eugênicos. Após esse período, Renato Kehl passa a dedicar-se à divulgação das teorias e à produção de material bibliográfico sobre elas.

A Fada Hygia, que será o objeto de análise, é produzido nesse contexto. O livro dirigido a crianças visa a transmitir de forma lúdica os preceitos eugenistas e, mais especificamente, higienistas, pois, como será tratado, uma das particularidades do movimento eugenista brasileiro se constitui nessa união entre higienistas e eugenistas. Tal obra de Kehl é uma entre as várias que adentram no campo da chamada "eugenia preventiva", que preconizava um modelo de eugenia em diálogo com a educação 
higiênica e com a reforma do meio, visto como fundamental para a regeneração das futuras gerações (STEPAN, 2004; SOUZA, 2006).

Assim, o objetivo deste artigo será primeiramente fazer uma explanação mais geral sobre o desenvolvimento das teorias eugênicas e o contexto que possibilitou seu desenvolvimento. Em seguida, terei foco sobre o movimento eugenista brasileiro e sobre a trajetória de Renato Kehl, figura essencial para essa análise. Por fim, discutirei como elementos de cunho eugenista e higienista estão inseridos na obra A Fada Hygia, quais os elementos utilizados e a forma de abordagem desses assuntos.

\section{Nasce uma nova ciência}

Em 1859 Charles Darwin publica A Origem das Espécies, que seria sua maior obra, detentora de grande influência sobre a ciências desde então. Sua publicação revolucionou o pensamento científico da época, sendo fonte de estudo e influência para dezenas de cientistas, entre eles, seu primo Francis Galton. Após ter contato com a obra, Galton passa a desenvolver suas próprias teorias, que culminam no livro $O$ Gênio Hereditário.

Além da influência de Darwin, Galton também é movido pelo contexto ao qual pertencia. Em meados do século XIX, as teorias sociais, raciais e os ideais imperialistas marcavam forte presença na Europa, o que contribuiu para que as publicações de Galton fossem bem recebidas no período. Outro fator importante é a redescoberta dos estudos de August Weismann e das pesquisas de Gregor Mendel sobre genética e as leis da 
hereditariedade humana, que acabam por legitimar suas teorias eugênicas e hereditárias (STEPAN, 2005).

As proposições galtonianas se difundem rapidamente pela Europa, e segundo apresenta Vanderlei de Souza (2006), antes da Primeira Guerra Mundial já havia ocorrido o desenvolvimento de sociedades eugênicas na Europa e Estados Unidos e um congresso sobre eugenia em 1912, que reuniu cerca de 750 cientistas e intelectuais de diferentes lugares do mundo, inclusive da América Latina. A partir daí, o desenvolvimento da eugenia passa a crescer exponencialmente.

Os objetivos desta nova ciência, posta inclusive como uma nova religião, são profundamente alinhados ao imperialismo e à promoção de uma raça superior, algo presente no âmago da sociedade europeia, que, desde seus primeiros contatos com outros grupos socioculturais, buscou se estabelecer como o de principal importância e capacidade de comando. Isso mostrou-se desde a dominação da América à África.

Essa necessidade de algo que legitimasse sua superioridade foi suprida então com as teorias eugênicas e antropométricas que também tiveram grande destaque no período. Para a elite branca que estava à frente dos movimentos eugênicos, um grande desagrado vinha ocorrendo já há algum tempo, o cruzamento racial. A prática era - e infelizmente para muitos ainda é - vista com maus olhos, pois essa união provocaria a degeneração da espécie. Somente o cruzamento entre indivíduos considerados dignos e da mesma "raça" deveria ser aprovado, pois mesmo membros dessa sociedade branca e elitista deviam ser selecionados já que 
até entre eles haveria degenerados que não podiam transmitir suas "taras hereditárias" às futuras gerações.

Estas "taras" não eram analisadas apenas na superficialidade de uma primeira geração, mas em avós, tios, primos, etc. Sua presença nas gerações que pudessem ser alcançadas deveria ser analisada a partir de exames pré-nupciais a fim de evitar o casamento com possíveis portadores de características hereditárias que iam desde doenças de caráter físico - como má formações - até doenças psicológicas e vícios, com o objetivo, conforme retratado por Pietra Diwan, de "implantar um método de seleção humana baseada em premissas biológicas" (DIWAN, 2007: 10).

A hereditariedade é um dos carros chefe da eugenia. Seria ela a responsável por todas as mazelas humanas. O casamento intrafamiliar, com pessoas portadoras de taras - depressão, má formações, alcoolismo, tabagismo, dentre outras doenças e características que consideravam aspectos de degeneração - em algumas sociedades consideradas pertencentes a outras raças, era desestimulado com a finalidade de garantir a transmissão apenas dos genes puros, a fim de depurar a humanidade.

A busca pela purificação foi feita através de diferentes abordagens. As três que mais se destacam ficaram conhecidas por "eugenia preventiva", "eugenia positiva" e "eugenia negativa". A segunda era voltada tanto para a reforma do meio como para a aplicação de exames pré-nupciais, evitando os casamentos considerados disgênicos. Nesse contexto, o matrimônio deveria ser consumado apenas com pessoas consideradas hereditariamente 
saudáveis e com saúde física e mental adequadas aos padrões postos, contribuindo assim com o bom desenvolvimento da espécie humana.

A "eugenia preventiva" buscava principalmente a instrução da população e a conscientização dela. É dentro dessa perspectiva que se inclui o livro A Fada Hygia, cuja existência é sintomática do cenário de elaboração de manuais para esse fim - dentro do qual vale destacar a extensa produção de Renato Kehl e as abordagens de temas como a higiene, a moral e o social. Essa política preventiva também se caracteriza como o meio em que mais se torna aparente a união entre eugenia e higienização, particularidade presente na eugenia brasileira.

Por fim, a "eugenia negativa" se caracteriza como uma forma extremista em busca da purificação radical a partir de medidas mais duras, como a esterilização eugênica ou mesmo a eutanásia. A partir dessa perspectiva, aqueles que não eram considerados dentro dos padrões eugênicos ou pertencentes à raça a qual se considerava digna de ser propagada não deveriam ter o direito de ter filhos, casar, ou, em casos mais radicais, o direito de viver (BLACK, 2003). Os maiores expoentes dessa teoria são sem dúvida o regime nazista, que durante a Segunda Guerra Mundial assassinou judeus, ciganos, homossexuais, portadores de doenças mentais, mas também países como os Estados Unidos, que, conforme apresenta Souza (2006), realizou esterilizações em massa de milhares de pessoas a partir do início do século $\mathrm{XX}$, muito antes da ascensão do nazismo na Alemanha. 
Essas perspectivas de abordagem entretanto não foram aplicadas de forma generalizada. Como pontua Stepan (2004), a eugenia nas regiões nórdicas e nos Estados Unidos apresentava um caráter mais radical e menos maleável quanto à miscigenação e outros meios de se alcançar a purificação. Já as regiões consideradas "latinas" dentro da Europa - Itália, Portugal, Espanha e França - e na própria América Latina, se caracterizam por uma eugenia mais maleável, principalmente no que compete a união com os movimentos higienistas. Nessas regiões, ao invés de um evolucionismo mais duro, pautado nas teses da genética mendeliana, teria se desenvolvido um evolucionismo neolamarckista, o que permitia pensar a educação, higiene e a reforma do meio como importantes no processo de regeneração da nação (STEPAN, 2004, 2005).

Devido a essas particularidades da eugenia brasileira, pesquisadores que se dedicaram a compreender a atuação dos movimentos eugênicos e higiênicos locais não se limitaram à história das Ciências, Cultural, Política ou da área médica, mas adentraram também a história da Educação. Isso se dá pelo fato de que, como aponta Maria Lucia Spedo Hilsdorf (2007), a expansão do ensino no Brasil - principalmente a educação pública -, com discussões mais profundas sobre seu currículo e abordagens, ocorre principalmente entre as décadas de 1910 a 1930, praticamente no mesmo momento em que as teorias eugênicas e higiênicas ganhavam força no país.

Contribui para isso ainda, segundo Hilsdorf, a tomada de consciência do Estado da função social da escola, além de seus usos políticos. Segundo ela, nos primeiros anos da Associação Brasileira de Educação (ABE), que 
buscava inserir o modelo educacional de ensino da Escola Nova, o órgão tinha "integrantes como médicos, higienistas e engenheiros" (HILSDORF, 2007: 82). Esses seriam grupos interessados em ter a escola como base de “campanhas políticas empreendidas para a modernização da sociedade brasileira" (HILSDORF, 2007: 82, grifos da autora). Essa atuação de eugenistas e higienistas no período foi muito presente no período por meio de manuais escolares, como o que este artigo busca analisar.

\section{Particularidades da eugenia brasileira}

A eugenia chega ao Brasil antes da Primeira Guerra Mundial, surgindo o termo pela primeira vez em 1914 em uma tese de medicina, segundo nos é apresentado por Stepan (2004). De acordo com Souza (2006), a eugenia já era debatida no Rio de Janeiro, na Bahia e em São Paulo mesmo antes do início da Primeira Guerra Mundial. De todo modo, a emergência da guerra na Europa mobilizava os intelectuais e as elites políticas brasileiras para pensar no processo de formação nacional, estimulando um amplo debate sobre a questão racial e o futuro do Brasil no chamado "concerto das nações" (SKIDMORE, 1976; SCHWARCZ, 1993).

É na Faculdade de Medicina do Rio de Janeiro que Renato Kehl teria contato pela primeira vez com teóricos do evolucionismo e com os ideais eugênicos. Kehl, que seria um dos principais incentivadores da eugenia e produtor de material sobre essa temática, se destacou no âmbito nacional devido à sua forte participação no desenvolvimento de sociedades eugênicas na América Latina. 
A eugenia brasileira - assim como a latina - é cercada de singularidades que a distinguem e que provocaram o pensamento de que ela não possuía presença significativa nesses locais a ponto de ser transformada em um objeto de estudo, perspectiva posta por Stepan (2004). Essa visão é desconstruída tanto por ela quanto por Maria Bernadete Ramos (2012), que analisa a presença da eugenia nas obras de Adalzira Bittencourt, mulher de grande presença na esfera pública no governo Vargas, tendo participado de importantes conferências sobre exames pré-nupciais, eutanásia e aborto, que ocorreram também em instituições de caridade. Além disso, Ramos (2012) encontra na obra de Bittencourt, intitulada Sua Excia. a presidente da República no ano de 2500 e publicada em 1929, mostras da profunda crença de que a eugenia regeneraria a nação brasileira e a faria ficar em pé de igualdade com as europeias.

Essa busca, no entanto, não poderia ser feita aos moldes da Europa, afinal, a sociedade brasileira e latinas possuíam uma constituição social distinta daquela. A América havia recebido um grande fluxo migratório de diversos grupos desde seu "descobrimento", além, é claro, do indígena, uma das "mazelas" da América, portador das mais diferentes degenerações, conforme acreditavam os eugenistas. Então, assim como seu processo de constituição teria sido diferente, sua purificação também deveria ocorrer a partir de outros meios.

Como a sociedade brasileira era constituída majoritariamente de mestiços, devido aos negros, indígenas e europeus que aqui viveram e que haviam se reproduzido sem qualquer controle por quase quatrocentos anos, 
existia além de uma busca pela purificação da raça, a busca pelo brasileiro (SCHWARCZ, 1993). O que era ser brasileiro afinal, em uma nação formada de outras nações? Acreditava-se, no início do século XX, que ao fim desse projeto de purificação eugênica os homens que surgissem dela seriam considerados os verdadeiros brasileiros.

Com tantos mestiços, negros, indígenas e pessoas vindas das mais diversas partes do globo, implantar a eugenia negativa não parecia ser a melhor solução. É nesse momento que se passa a apostar na higienização como modo de eugenizar a sociedade, algo proposto por Renato Kehl. Assim a união com o movimento higienista vem para auxiliar ambas as ciências a alcançar seus objetivos, pondo a "eugenia positiva" e a "preventiva" como as principais armas dos eugenistas brasileiros.

Os movimentos higienistas tinham como foco principal as áreas sem saneamento básico onde se proliferavam doenças e, acreditavam eles, onde poderia se encontrar, majoritariamente, os chamados "degenerados". O campo também era foco desses grupos. Os ditos sertanejos, pessoas simples que possuíam condições de moradia, acesso a saúde e a saneamento precárias, também eram apontados como pontos chave nessa busca pela higienização.

O sertanejo, posto como ignorante, disgênico e degenerado, assim como as populações periféricas, mestiças, insalubres, consideradas repletas de vícios e promiscuidade, possuíam especial atenção dos sanitaristas. Eles consideravam que o meio poderia provocar a mudança nessas pessoas, regenerá-las. Por isso o investimento em políticas de cunho higienista, 
mostrando mais uma vez como a eugenia brasileira foi peculiar frente à europeia de modo geral, pois aceitava - até certo ponto - que se associasse à formação do homem o ambiente e não unicamente a hereditariedade.

Outra particularidade é quanto à miscigenação, tão mal vista na Europa, mas no Brasil entendida como um dos meios de se branquear a raça. A união entre negros e brancos acabaria por branquear a raça dentro de algumas gerações devido à "força superior" dos genes brancos que acabariam por prevalecer e branquear a nação. Essa posição foi defendida por Kehl durante os primeiros anos de sua luta pela eugenização da nação, marcados pela "eugenia preventiva" e "eugenia positiva". No entanto, por volta de 1928, após viagens ao leste europeu, Kehl passa a se desligar desses ideais e se vincular à "eugenia negativa".

\section{Higienistas e eugenias na obra "A Fada Hygia" 1937}

A eugenia buscou diversos meios de difundir suas ideias. Uma delas foi a produção de manuais que seriam responsáveis pela disseminação de preceitos higiênicos e eugênicos de forma sucinta e clara para as populações consideradas estratégicas por eles, como os moradores das periferias, favelas e sertões. Naquele momento, governos de diversas partes do mundo investiam em políticas higienistas e eugenistas a fim de aplicar essas teorias.

No Brasil não foi diferente, tendo o governo investido em diversas áreas, com ênfase nas de reurbanização das cidades e de educação. Ademais, pessoas de grande relevância dentro desses movimentos atuaram 
diretamente no interior do governo, assumindo altos cargos, como é o caso do médico Belisário Penna, que atuou no Serviço de Profilaxia Rural e na Diretoria de Saneamento Rural do Departamento Nacional de Saúde Pública; e do próprio Renato Kehl, vinculado ao Departamento Nacional de Saúde Pública.

A Fada Hygia é um dentre os vários manuais produzidos por Renato Kehl no período mais "positivo" de sua carreira. A primeira edição data de 1925. Kehl só se ligaria a vertentes eugênicas mais radicais a partir de 1928 e, apesar do exemplar analisado já ser a $5^{\mathrm{a}}$ edição da obra, lançada em 1937, não fica perceptível nela um discurso ligado à "eugenia negativa" prevalecendo ainda um discurso ligado ao movimento sanitarista e à “eugenia preventiva”. A partir desta edição, ele teria sido reimpresso, segundo Carolina Toshie Kinoshita, com "modificação nas ilustrações e adaptação ortográfica" (KINOSHITA, 2013: 95). O livro foi utilizado na rede pública de ensino e foca na instrução a crianças, dando a noção de que o autor acreditava que estas, após terem contato com as ideias, além de porem-nas em prática também as transmitiriam a seus familiares. Isso fica mais claro na apresentação do livro, em que Kehl declara que "a professora ou professor lerá ou determinará que as crianças leiam um capítulo por dia, explicando o que ouviram ou leram e a razão higiênica de cada conselho, quando forem inquiridas" (KEHL, 1937: 9).

Ricamente ilustrada, a obra voltada para crianças possui uma linguagem adequada a elas, tendo como princípio de ensino o exemplo. A todo momento situações são apresentadas e elas servem de modelo sobre o 
que é correto ou não se fazer. Outro detalhe importante são as divisões do livro. Formado por aproximadamente 180 páginas, apenas 51 são destinadas à história Fada Hygia, situada na primeira parte. As demais páginas, pertencentes à segunda parte, são compostas pelos conselhos da fada Hygia, orientações ricamente ilustradas sobre diversos assuntos.

A primeira parte da obra é dividida em cinco capítulos. O primeiro, trata de introduzir a fada, descrever o local onde ela vive e recebe as crianças, além de já apresentar a temática central do livro: a saúde e a higiene. Isso ocorre por meio de um monólogo da fada, definida como

[...] a fada da saúde. [Que] Ensina aos sãos a conservar a vida, a bem vivê-la, com prazer e satisfação. Dá conselhos aos doentes para adquirirem de novo a força e a robustez e para não propagarem aos outros os seus males (KEHL, 1937: 17).

Feita essa apresentação da personagem principal, inicia-se o primeiro capítulo e conselho da fada às crianças, falando sobre como a saúde é um bem precioso que deve ser protegido.

É nesta parte que classes sociais são citadas pela primeira vez. De forma rápida, a fada diz que não há riqueza maior que a saúde, e que "ha [sic] ricos doentes, para os quais a vida é um martírio. Ha [sic] pobres sadios que levam o tempo a cantar e a bendizer a sorte". (KEHL, 1937: 20). Dessa forma, ela passa a ideia às crianças de que qualquer pessoa, seja de classe alta ou baixa, está suscetível a doenças. No entanto, com a discussão que se inicia em seguida sobre as formas de se conservar a saúde, e com o modo como a história se desenvolve, fica claro que as classes mais baixas, 
que vivem mais próximas à linha da extrema pobreza e nas periferias da nação, são as pessoas que mais sofrem de doenças decorrentes da falta de higiene e, consequentemente, as que mais necessitam do manual para corrigir suas faltas e restabelecer a saúde.

O primeiro conselho também gira em torno da importância do ar, de sua qualidade e de se viver e brincar em ambientes arejados, já que, segundo a fada Hygia, "as crianças que respiram ar puro são rosadas e fortes". Já não acontece o mesmo às que respiram ar dos quartos que estão sempre fechados, ou o ar cheio de poeiras, isto é, de impurezas. Essas são "pálidas, preguiçosas, nunca se riem, não acham graça nos brinquedos" (KEHL, 1937: 21).

Após o fim do conselho, a fada convida as crianças a passearem pelo jardim, onde encontra um dos principais antagonistas e fonte de exemplos para suas histórias. Trata-se de um menino sentado debaixo de uma árvore, sem ânimo para brincar. Indagada pelas crianças sobre o motivo da recusa do menino para brincar, ela responde:

Ele não tem vontade de brincar porque está doente, sente-se fraco, desanimado. E isso porque dorme e passa todo o tempo dentro de casa, sem respirar ar livre. Agora como está seguindo os meus conselhos e vem respirar o ar fortalecedor e fresco desse jardim, vai ficar, dentro de pouco tempo, rosado e alegre (KEHL, 1937: 23-24).

É no segundo capítulo que essas crianças são devidamente apresentadas. Trata-se de Tonico e Jeca - creio que em alusão ao 
personagem Jeca Tatu de Monteiro Lobato, entusiasta das ideias eugênicas e financiador de publicações - crianças que moram "pelas redondezas do palácio, com seus pais, que além de pobres são muito ignorantes" (KEHL, 1937: 27). O pai era operário e ganhava o suficiente para alimentar e vestir as crianças, a mãe - como a grande maioria das mulheres naquela época ficava responsável pelos afazeres do lar. Aqui, novamente, a relação entre classe e pobreza é perceptível. O pai dos meninos, como um simples operário, não possuiria nem condições econômicas nem intelectuais para compreender e prover à família condições dignas de vida.

Nesse capítulo, a fada Hygia traz duas lições às crianças. A primeira, referente à desobediência; a segunda, aos riscos com a água. Ela fala para as crianças como Jeca e Tonico eram bagunceiros e fugiam de casa para brincar, principalmente devido à ausência paterna e constante ocupação da mãe. Essas fugas resultariam em problemas de saúde a eles.

No primeiro exemplo, um deles ficou de cama por vários dias pois ao invés de ir para casa depois da escola decidiu ir brincar em um rio. Tempos depois, novamente uma das crianças adoece pois, segundo a fada, "quando sentiam sêde [sic], bebiam qualquer agua [sic] que encontravam, fosse de rio, de poço ou de biquinha" (KEHL, 1937: 30). Desta vez, Tonico, a criança que adoecera, ficara fraco, de cama e tendo que tomar remédios amargos. Esse capítulo tinha por função explicar os cuidados que se deveria ter com a água, pois se ela não viesse de uma fonte confiável, não fosse fervida ou filtrada, poderia causar uma série de doenças devido às bactérias e aos microrganismos presentes nela. Inclusive, o livro, além de ilustrado 
com as imagens das crianças brincando, delas doentes e da fada, também traz a ilustração de um microscópio, pouco conhecido pelo público geral naquele período, e uma explicação de como ele funcionava.

O terceiro capítulo gira em torno da casa de Tonico e Jeca. É onde a fada Hygia irá discorrer sobre as características ideais de uma casa, bem como sobre a forma correta de limpá-la. O ponto de partida se dá quando a fada descobre que Tonico está melhor e já pode receber visitas. Assim, ela convida as outras crianças e vai à casa dele. Após entrarem na casa - a qual a mãe dos meninos estava limpando - a fada Hygia percebeu a falta de higiene que havia no local. A forma como a mulher limpava a casa, fazendo com que a poeira se levantasse, não era adequada.

Ao ver tal cena, ela decide aconselhar a mãe das crianças acerca de como se deve fazer a higiene correta do local, mas utilizando-se de um certo tato para não ofender a mulher. Ela explica que deve-se dar preferência a um pano úmido ao invés de vassouras, para levantar menos pó, assim como explica que as janelas devem ser abertas para arejar a casa. A fada também fala dos males dos quartos em forma de alcova - sem janelas - como era o de Tonico e Jeca, muito prejudiciais à saúde, indicando, conjuntamente, os melhores espaços para se construir uma casa, longe de estábulos, matas, rios, etc. Por fim, a fada aponta para uma residência ao longe e pergunta às crianças se a conhecem. Prontamente, uma responde que sim, que trata-se de um lugar onde moram "dois meninos muito magros, palidos [sic] e feios; doentes com certeza. A mãe parece um 
esqueleto" (KEHL, 1937: 39). Segundo a fada, a família só era assim devido à falta de higiene.

Aqui, mais uma vez, as relações entre higiene e pobreza são abordadas. As mazelas da família não seriam causadas por questões de desigualdade social necessariamente, mas simplesmente por falta de asseio. Essa crença de que a pobreza não é motivo para a falta de higiene é muito problemática, pois como se quer que pessoas que não possuem condições econômicas de ter moradia e uma alimentação minimamente segura e saudável tenham acesso a produtos de higiene igualmente seguros?

Apavorada com o que poderia acontecer com sua família, a mãe dos meninos se dispõem a melhorar as condições de higiene na casa. Esse capítulo, em particular, traz importantes informações sobre como a mulher era vista dentro dos movimentos higiênicos e eugênicos. Conforme Kehl deixa claro na apresentação do livro intitulada algumas palavras, "a vós, mães brasileiras, e a vós, mestres, incumbe concorrer para que as crianças, a vosso cargo, se tornem cidadãos fortes, belos e disciplinados" (KEHL, 1937: 10).

O papel das mulheres dentro desses movimento era ao mesmo tempo passivo, devido à falta espaço para que elas discutissem o que pensavam sobre tais ideias, e ativo, já que elas tinham o papel - considerado fundamental - de gerar filhos saudáveis e fortes para a nova nação que era almejada. A elas cabia dar à luz essas crianças, assim como cuidá-las e educá-las em seus primeiros anos. Isso era uma função exclusivamente feminina. Em momento algum o pai das crianças é citado - para além da 
profissão, ele não tem papel na educação dos filhos ou nos cuidados com a casa. Sua função é ser o provedor e chefe da família. Educar os filhos era função da mãe, fosse no sentido das letras fosse no sentido da higiene e bons modos. Qualquer falta ou desvio do tipo identificado na criança não era uma falta dos pais no sentido coletivo da criação dos filhos, mas um erro exclusivamente feminino, da mãe e esposa, a primeira educadora das crianças. $\mathrm{O}$ conto deixa isso claro ao não citar em momento algum qualquer falta de atenção por parte do pai de Tonico e Jeca, recaindo sobre a mãe toda a culpa.

No quarto capítulo, um pouco mais curto, as crianças se reúnem novamente na casa de Tonico e Jeca, ponto de encontro para uma caminhada - descrita como algo muito saudável e revigorante - com a fada Hygia. Nesse momento, a fada percebe como a casa está mais bem cuidada, com janelas abertas e o quintal limpo e florido. Quando as crianças chegaram, sentaram-se sob uma árvore e começaram a conversar, momento em que a mãe dos meninos declara que eles "estão agora bem mais fortes e corados, comem bem, não fazem extravagâncias, não andam à cata de gulodices nem comem fóra [sic] de hora, o que faz tanto mal ao estômago" (KEHL, 1937: 42).

Aproveitando a fala da mãe dos meninos, a fada Hygia aproveita o momento para falar sobre a alimentação adequada, enfatizando como ela deve ser equilibrada pelo consumo de vários tipos de alimentos, além de ser necessário ter o cuidado de saber a procedência deles, não comendo nada que não se considere de origem segura. Ela fala também sobre os horários 
Cadernos de Clio, Curitiba, v. 11, nº. 2, 2020

corretos para cada refeição. Dados os conselhos, a fada convida as crianças para irem à sua casa para a ceia de Natal. Esse capítulo novamente deixa claro as mudanças cotidianas - principalmente no cotidiano feminino - que a eugenia e higienização trouxeram.

Passa-se a haver um modo eugênico e higienicamente adequado para se fazer praticamente tudo. As mulheres precisavam reaprender ou, como deixa a entender o livro, serem ensinadas a fazer suas atividades domésticas da "forma correta". Houve uma tentativa de higienização e eugenização do cotidiano, buscando reformular práticas e hábitos presentes há gerações no modo de viver da população, principalmente daqueles considerados alvos dessas políticas.

No quinto e último capítulo, questões relacionadas a vestimentas e asseio do corpo são abordadas. Após irem à igreja, as crianças se dirigem à casa da fada, a fim de cear e receber presentes - único momento em que qualquer coisa relacionada à religião é citada ao longo da história, mas sem grandes aprofundamentos. Apenas diz-se que o Natal é o dia do nascimento de Jesus e que pela manhã as crianças teriam ido à missa com suas melhores roupas, assunto abordado no capítulo. Quando as crianças chegam, imediatamente a fada percebe problemas com suas roupas. Algumas da estação errada, outras sujas ou muito pequenas. Ela, entretanto, se conteve e deixou para fazer comentários depois do jantar. Este, por sua vez, transcorre de uma maneira exemplar, seguindo todas as boas regras de conduta, como ela desejava. Ao fim da refeição, convida as crianças para se 
aproximarem da árvore de Natal e questiona a maneira correta de se vestir. Após receber uma resposta ela declara que

[...] se devem usar as roupas de acordo com o clima e as estações do ano. As roupas de baixo precisam ser sempre brancas, porque são mais higiênicas. É necessário trazê-las limpas, trocando-se pelo menos três vezes por semana, porque elas se embebem de suor, sujam-se de poeira, de gorduras, de descamações do corpo e se enchem de microbios [sic], tornando-se por tudo isso, infectadas e desagradáveis à vista $\mathrm{e}$ ao olfato. É preferível andar com roupas remendadas e limpas, do que com elas sujas, embora novas e de seda (KEHL, 1937: 47-48).

Dito isso, a fada Hygia também falou sobre cuidados com a higiene, sobre como se deve tomar banho com frequência, preferencialmente todos os dias, com água fria - por ser mais fácil de se obter - e durante a manhã, e sobre a importância de cuidados com os dentes. Aconselhou o uso de chapéu, para precaver do sol, e sapatos, para evitar doenças. Para as meninas, ela desaconselhou o uso de coletes e roupas apertadas que deformam o corpo, pois prejudicam os órgão e sua forma natural. Por meio disso, é perceptível uma tentativa de normatização dos corpos, a fim de garantir uma estrutura corporal considerada eugenicamente adequada, além de criar um padrão que seria socialmente aceito e que deveria ser seguido. Não se devia comer demais para ser gordo, nem de menos ao ponto de ter uma magreza extrema.

A segunda parte do livro, composta pelos "conselhos da fada Hygia", é uma seção também ricamente ilustrada, que tinha o objetivo de informar 
sobre algumas questões consideradas de conhecimento essencial. São dezenove tópicos enumerados: ar, água, alimento, habitação, asseio do corpo, exercícios físicos, maus hábitos, o sono, as vestes, atitude, os micróbios, as moscas, as doenças, vícios, vermes intestinais, mosquitos, animais e animálculos, bons hábitos e alguns conselhos mais. Esses tópicos ilustrados davam exemplos de como se construir adequadamente as casas, poços e latrinas, bem como traziam informações e conselhos básicos sobre cada um deles.

Por fim, havia também mais quatro seções dentro dessa segunda parte, para além do conselhos da fada Hygia: agentes e modos de propagação das principais doenças contagiosas, com pequenas ilustrações legendas sobre as cinco principais formas de se transmitir doenças; preceitos de prática cotidiana para a conservação da saúde, com 11 ilustrações com legenda sobre atividades essenciais no dia a dia para se manter saudável; saúde e alegria, em que se fala aquilo que faz os homens saudáveis e alegres; um item principalmente ligado ao trabalho, colocado em oposição à preguiça e à vadiagem, e relacionado ao espírito e a exercícios ginásticos, no qual ilustrações indicavam a forma de se fazer os mais variados exercícios para se manter a saúde física e mental.

A segunda parte, pelas características citadas, era mais voltada para o público adulto. Apesar da escrita ser simples, separada por tópicos e de caráter explicativo, é importante lembrar que esse material tinha como principal função educar crianças e, depois, os pais. É importante também pensar a que público o livro era dirigido. Ao longo de toda a leitura do 
conto, e dos conselhos da fada Hygia, fica claro que o principal público alvo era a população do campo, considerada ignorante e desprovida de conhecimento pelo movimento eugênico. É frente a essa parcela que conhecimentos poderiam ser aprofundados, a fim de se ter o repertório necessário para sanar as dúvidas que poderiam surgir entre as crianças.

As ilustrações presentes na obra podem ser divididas em duas categorias distintas: primeiro, aquelas que estão dispostas ao longo do conto de Fada Hygia, e em segundo lugar as que compõem a seção $O s$ conselhos da Fada Hygia. A única ilustração colorida é a capa, na qual a fada aparece com um grupo de crianças formando um círculo de mãos dadas, como se dançassem uma ciranda. Nenhuma das crianças possui pele escura e todas compartilham de características fenotípicas ligadas a ascendências caucasianas.

As primeiras ilustrações do conto giram em torno da fada acompanhada das crianças brincando em seu grande jardim, sempre tendo seu castelo ao fundo, claramente dotado de características europeias. A primeira ilustração que parece retratar um personagem com características das populações afrodescendentes refere-se a quando a fada e as crianças encontram Jeca sentado debaixo de uma árvore. Este possui características fenotípicas ligadas a esses grupos, como cabelo encaracolado. No entanto, as características não se mantém em ilustrações posteriores de Jeca e seu irmão, onde suas características são ligadas a populações europeias - no entanto, não fica claro se a alteração teria ocorrido por se "curarem", já que um dos meninos ainda de cama já possuía tais características alteradas. A 
última ilustração do conto é da fada e das crianças dançando ciranda em volta da árvore de Natal. Assim, no conto, as imagens possuem um caráter principalmente ilustrativo.

As ilustrações estão presentes com maior peso na segunda parte do livro, em que elas são utilizadas principalmente de forma técnica, a fim de demonstrar como se construir adequadamente as casas, latrinas, poços e quais os locais mais adequados a tais construções. Se fazem presentes também para apresentar a postura correta frente a situações como tossir, espirrar e se sentar, além de trazerem ilustrações de alguns patógenos de doenças comuns, como vermes, moscas e cobras. Essencialmente, as ilustrações desse trecho têm o objetivo de instruir e guiar o leitor para a prática de seus ensinamentos. Novamente, todas as pessoas possuem características fenotípicas europeias, ligadas a pessoas brancas, o que pode indicar o ideal do volume por um branqueamento populacional.

\section{Conclusão}

O contexto em que a obra é desenvolvida em grande parte a explica. O Brasil possuía um grande número de analfabetos, a educação chegava a poucos, as condições de saneamento eram precárias e as de saúde mais ainda. Ondas de pestes e viroses eram frequentes tanto em centros urbanos quanto no campo.

A Fada Hygia surge nesse momento como um dos meios de se combater essas mazelas e, ao mesmo tempo, proliferar os ideais de uma pequena elite de intelectuais responsáveis por sua produção. Movidos pelo 
anseio pela modernidade, esses intelectuais se utilizaram de seu poder de influência para tentar moldar o mundo segundo aquilo que consideravam o melhor, sem, no entanto, consultar aqueles que seriam mais afetados.

O livro demonstra como grandes investimentos foram feitos em tentar sanitizar e eugenizar o Brasil, principalmente as regiões consideradas mais problemáticas, como os sertões, as favelas e o interior do país no geral. É possível perceber como se tentou inserir uma forma eugênica e higienicamente adequada de se viver, a fim de evitar a "degeneração" nacional. A partir disso, também é possível compreender como a elite brasileira via as populações excluídas da sociedade enquanto ignorantes degenerados que dependeriam dela para serem salvos, evitando, ao mesmo tempo, que o país afundasse em suas mazelas.

As divisões e papéis de gênero também ficam claras. A todo momento, apenas as mães são colocadas como responsáveis pela educação dos filhos, algo que somente recentemente - e ainda de forma lenta - vem sendo desconstruído na sociedade. O sucesso ou fracasso da nação idealizada pelos movimentos que patrocinaram produções como $A$ Fada Hygia dependia diretamente do êxito dessas mulheres em criar seus filhos.

A produção sobre esse movimento de intelectuais no Brasil ainda se encontra em desenvolvimento pois só recentemente se passou a investir nessa área de estudos, principalmente devido às múltiplas facetas da eugenia brasileira, que, como nos é apresentado por Souza e Wegner (2018), foi empregada em projetos políticos e científicos de seleção social e de reforma nacional. Mas, felizmente, como ambos colocam, conta-se com 
amplo acervo de fontes para o desenvolvimento de pesquisas em decorrência da grande difusão do movimento e de sua institucionalização.

\section{Referências}

BLACK, Edwin. A Guerra Contra Os Fracos: a Eugenia e a Campanha Norte-americana para Criar uma Raça Superior. São Paulo: A Girafa, 2003.

DIWAN, Pietra. Raça Pura: uma história da eugenia no Brasil e no mundo. São Paulo: Contexto, 2007.

HILSDORF, Maria Lucia Spedo. História da Educação Brasileira: Leituras. São Paulo: Thomson Learning, 2007.

KEHL, Renato de Ferraz. A Fada Hygia. 5. ed. São Paulo: Livraria Francisco Alves, 1937.

KINOSHITA, Carolina Toshie. Um D. Quixote cientifico a pregar para uma legião de panças: os manuais escolares de higiene à sombra da eugenia (1923-1936). 2013. 192 f. Dissertação (Mestrado em Educação) Faculdade de Educação, Universidade Estadual de Campinas, Campinas (SP), 2013.

RAMOS, Maria Bernadete. Ao Brasil dos meus sonhos: feminismo e modernismo na obra de Adalzira Bittencourt. Rev. Est. Fem., Florianópolis, ano 10, n. 1, p. 11-37, jan./jun. 2012.

SCHWARCZ, Lilia. O espetáculo das raças. São Paulo: Companhia das Letras, 1993.

SKIDMORE, Thomas. Preto no branco: raça e nacionalidade no pensamento brasileiro. São Paulo: Paz e Terra, 1976.

SOUZA, Vanderlei Sebastião de. A política biológica como projeto: A "eugenia negativa" e a construção da nacionalidade na trajetória de Renato 
Kehl (1917-1932). 2006. 220f. Dissertação (Mestrado em História das Ciências) - Casa de Oswaldo Cruz, Fiocruz, Rio de Janeiro (RJ), 2006.

SOUZA, Vanderlei Sebastião de; WEGNER, Roberto. História da eugenia: contextos, temas e perspectivas. In: TEIXEIRA, Luiz Antonio; PIMENTA, Tânia Salgado; HOCHMAN, Gilberto (Org.). História da Saúde no Brasil. 1 ed. São Paulo: Hucitec, 2018.

STEPAN, Nancy. A Eugenia no Brasil - 1917 a 1940. In: HOCHMAN, Gilberto; ARMUS, Diego. Cuidar, Controlar, Curar: ensaios históricos sobre saúde e doença na América Latina e Caribe. Rio de Janeiro: Editora Fiocruz, 2004.

. "A hora da eugenia": raça, gênero e nação na América Latina. Rio de Janeiro: Editora Fiocruz, 2005.

Recebido em: 05/03/2021 Aceito em: 11/05/2021 